\title{
Judicial Decision-Making, Ideology and the Political: Towards an Agonistic Theory of Adjudication
}

\author{
Rafał Mańko ${ }^{1,2}$ (D) \\ Accepted: 27 February 2021 / Published online: 30 March 2021 \\ (C) The Author(s) 2021
}

\begin{abstract}
The present paper puts forward a first outline of a possible agonistic theory of adjudication, conceived of as an extension of Chantal Mouffe's agonistic theory of democracy onto the domain of the juridical, and specifically, judicial decisionmaking. Mouffe's concept of the political as the dimension of inherent and unalienable conflicts (antagonisms) which, nonetheless, need to be tamed for a pluralist democracy to function, creates an excellent vantage point for a critical theory of adjudication. The paper argues for perceiving all judicial decisions as having a double nature-juridical and political. Cloaked in legal form, judgments nonetheless decide on individual instances of on-going collective conflicts, opposing workers to employers, consumers to traders, tenants to landlords, moral progressives to traditionalists, minorities to majorities and so forth. Judges, when handing down judgments, enjoy a 'relative sovereignty', being always already inscribed into the institutional imperatives of the juridical, on one hand, and ideological influences, on the other, but at the same time called upon to decide in the terrain of the undecidable and contingent (after all, law does not 'apply itself' on its own). Indeed the determinacy of legal decisions is only relative: in many cases judges can, by performing a sufficient amount of legal interpretive work, reach a conclusion which will be different from the prima facie interpretation. The collective conflicts of a various nature (economic, ideological, socio-political), once they are juridified, become the object of judicial decisions which, in light of Mouffe's theory, can be seen as temporary hegemonic fixations. The goal of critical legal scholarship is to destabilise such hegemonies in the name of justice. This can be done not only through an external critique of the law, but also through an internal one. The methodological approach advanced in the latter part of the paper emphasises the need for a critique of judicial decisions based on the consideration of all possible alternative decisions a court could have reached, and their evaluation in the light of conflicting interests and ideologies.
\end{abstract}

Keywords Adjudication · Agonistic theory · Ideology $\cdot$ Law and democracy $\cdot$ The political 


\section{Introduction}

The relationship between judicial decision-making, ideology and the political is certainly not a new topic for critical legal theory. For decades, Duncan Kennedy (e.g. 1997, 2008, 2015) has been developing a critical theory of adjudication, focusing on the judge as a self-conscious actor aiming to mould case-law in a specific ideological direction. On the other side of the Atlantic, Costas Douzinas and Adam Gearey (2005, pp. 162-176) have looked into the ethics of adjudication, drawing inspiration from Levinas and Derrida, followed later on by Lindroos-Hovinheimo (2012) who explored the ethics of legal interpretation. These approaches-focusing on the judge's subjective position (Kennedy 2008, p. 4) and her ethical duties (Douzinas and Gearey 2005, p. 171; Lindroos-Hovinheimo 2012) — undoubtedly tell an important part of the story. Yet in this paper I wish to take another theoretical path based on a rather different theoretical starting point. I will try to look at judicial decision-making-the core component of adjudication-through the lens of the concept of the political, as used by Chantal Mouffe as part of her concept of agonistic democracy. Political philosophers and theorists of democracy do not usually delve into the implications of their concepts for the juridical (Bator 2020, p. 11) and Mouffe is no exception here. Given the fact that her theory does not address the question of adjudication, but only parliamentary law-making, the principal aim of my paper is to put forward a critical theory of adjudication that will be congruent with Mouffe's conception of democracy. Given that 'agonistic democracy privileges plurality, difference and contestation' (Breen 2009, p. 133), in my theoretical project the judge, as decision-maker, will be portrayed as someone arbitrating between conflicting (antagonistic) interests - in every single case that is adjudicated-on the assumption that political conflicts do not come to an end when legislation is enacted, but they continue in the courtroom (Bator 2020, p. 28).

In this vein, the paper argues for perceiving all judicial decisions as having a double nature-juridical and political. Cloaked in legal form, judgments nonetheless decide on individual instances of on-going collective conflicts, opposing workers to employers, consumers to traders, tenants to landlords, moral progressives to traditionalists, minorities to majorities and so forth. Judges, when handing down judgments, enjoy a 'relative sovereignty', being always already inscribed into the institutional imperatives of the juridical, on one hand, and ideological influences, on the other, but at the same time called upon to decide in the terrain of the undecidable and contingent. I will further argue for a specific way of analysing (and critiquing) judicial decisions against the background of all possible alternative interpretations that were either openly considered and discarded in the judgment itself, or even not taken into account (at least not in the text of the judgment). As Rodin and Perišin point out, 'each legal norm is the product of a particular political conflict where one side won. Thus, legal norms are a snapshot of the distribution of power in political battles that created those norms' (Rodin and Perišin 2018, p. 7). A fortiori, this is applicable to court judgments: each of them can be perceived precisely as a snapshot of the on-going agonistic struggles 
within society, or in other words 'the outcome of a momentary power relationship between the representatives of conflicting social groups' (Łakomy 2020, p. 87).

\section{The Political: Taking Antagonisms Seriously}

Critical legal thinking 'by necessity' involves 'a thinking of the political' (Stone et al 2014, p. 4) but without falling into the trap of oversimplification and 'treat[ing] law as a mere instrument of political power' or as 'politics by other means' (ibid., p. 1). With the aim of providing a framework for 'thinking of the political' in adjudication, this paper draws on Chantal Mouffe's agonistic theory of democracy ${ }^{1}$ and makes an attempt at transposing it onto the domain of the juridical as an agonistic theory of adjudication. There are essentially two, mutually exclusive, conceptions of the political: Arendtian and Schmittian (Schaap 2007, p. 70; Jones 2014, p. $161 \mathrm{cf}$. Jezierska 2011, p. 125). By opting for Mouffe, I subscribe to the Schmittian tradition whereby the political is a 'space of power, conflict and antagonism' (Mouffe 2005, p. 9); this means eo ipso rejecting the Arendtian model of the political as 'a space of freedom and deliberation' (ibid.), a model which does not seem to fit well to the reality of adversarial litigation and adjudication.

Mouffe's theory ${ }^{2}$ is, first and foremost, a vehement gesture of rejection of the post-political model of democracy in which conflict is replaced by the alleged possibility of rationally reaching consensus (Roskamm 2015, p. 385; Monteiro Crespo de Almeida 2020, p. 466; cf. McNay 2014, p. 67) as, in particular, per deliberative democrats such as Rawls and Habermas (Breen 2009, p. 136; Menga 2017, p. 540; Jones 2014, p. 15). For Mouffe, conflicts are 'the core of democratic politics' (Jezierska 2011, p. 120). In highlighting conflict, rather than consensus, and emphasising its a priori character (Sulikowski and Wojtanowski 2019, pp. 190-191) and

\footnotetext{
1 Some critics accuse Mouffe of 'turning away from an analysis of determinate social relations' and getting 'stuck in an abstract mode of reasoning' (McNay 2014, p. 96). In my view, this can hardly be a valid critique of political theory or political philosophy, as opposed to sociology of politics or empirically oriented political science. The former are reflections on the political, and the latter are an empirical study of politics (Jezierska 2011, p. 124).

2 The relation of Mouffe's theory to, on one hand, Schmitt, and on the other hand, deliberative theories (Arendt, Rawls, Habermas), has attracted critique. For some, Mouffe's theory is 'unbridgeable' with Schmitt's (Menga 2017, pp. 542-544; 2018, pp. 105-110; cf. Dyrberg 2009; Roskamm 2015, pp. 386391) and her concept of agonism is too broad, as it covers both potential and actual conflicts (Menga 2017 , pp. 546-549). For others, her theory is too close to deliberative understandings of democracy, and therefore not radical enough, espousing a vision of politics 'that is in its essential distinctly deliberative' (Breen 2009, p. 139; cf. Knops 2007, p. 117). However, Gürsözlü (2009) downplays the common elements of agonistic and deliberative theories while Knops (2012, pp. 167-168) argues that agonistic and deliberative models of democracy are actually congruent. I agree with Matthew Jones (2014, p. 22) who claims that Mouffe's vision is one of 'conflictual consensus' that 'refers only to an agreement on the preset rules of the game', in contrast to Rawls and Habermas who believe that a substantive consensus can also be reached. In any event, what could perhaps be treated as weaknesses for a comprehensive theory of radical democracy (which is another issue) are, nonetheless, perfectly useful building blocks for an agonistic theory of adjudication because adjudication by definition presupposes the submission of a conflict to the authority of the judge and, due to its structure as discourse, is deliberative and agonistic at the same time.
} 
the continuing importance of the friend/enemy distinction pace Arendt, Rawls and Habermas (Breen 2009, p. 136), Mouffe nonetheless underlines the need to keep the political at bay by subjecting it to a set of rules-embedded in adequate institutional arrangements-preventing the dissolution of democracy itself (Mouffe 2013, ch. 1 and 9; cf. Monteiro Crespo de Almeida 2020, p. 467). Indeed, in line with Mouffe's theory, the agon can and should be kept within the borders of the political community (Mouffe 2005, p. 14; 2013, ch. 1). 'Conflict, in order to be accepted as legitimate'-explains Mouffe - 'needs to take a form that does not destroy the political association' (2005, p. 20). Consequently, for it to be possible to keep the antagonism within the political community, and even simply to 'make human coexistence possible' (Mouffe 2018, p. 91), Schmittian enemies are transformed, in Mouffe's theory, into adversaries; sovereignty becomes overshadowed by proceduralism; and the singularity of the event gives way to the cyclical nature of democratic processes (Smoleński 2012, pp. 67, 74-75, 78). This aspect of Mouffe's thought, which goes 'against Schmitt,' allows to 'tame' (Mouffe 2000, p. 107), 'sublimate' (Mouffe 2013, p. 9) and 'defuse' (Mouffe 2018, p. 91) the political, transforming the antagonism into an agonism, ${ }^{3}$ the latter being 'compatible with pluralist democracy' (Mouffe 2005, p. 19). Agonistic adversaries, unlike antagonistic enemies, 'see themselves as belonging to the same political association, as sharing a common symbolic space within which the conflict takes place' (Mouffe 2005, p. 20). They accept the common rules of the democratic game (Jones 2014, pp. 21-22) and participate in the agon, i.e. a "struggle (...) conceptualized not as "war" but as "contest," a struggle with roles and without destruction' (Roskamm 2015, p. 385). In the words of Mouffe, '[a]dversaries do fight-even fiercely_but according to a shared set of rules, and their positions, despite being ultimately irreconcilable, are accepted as legitimate perspectives' (Mouffe 2005, p. 52). This also has a consequence for pluralism which must have limits and cannot be fully unconstrained (Jezierska 2011, pp. 121-122).

Collective identities of social groupings play an important place in Mouffe's theory, where 'identities have no essence but can gain meaning only through the exclusion of its "constitutive other" (Yamamoto 2017, p. 392), the antagonism being 'an ever-present moment of identification' (ibid., p. 391). They are not the reason of conflict (which would be Schmitt's position); rather, it is in conflict that identities are constructed (Sulikowski 2018, p. 84) through the formation of a chain of equivalences (Laclau and Mouffe 2001, p. 127ff; Jezierska 2011, p. 117). They are accidental, not essential (Mouffe 2018, pp. 88-90). The 'line of division is (...) always fluid and opaque as there are no stable identities' (Jezierska 2011, p. 126) - identity is rather 'inherently dislocated' (ibid., p. 130). Negativity is at the root of identity which is formed when the 'different groupings unite because of (...) a shared antagonist. They unite against something' (Jezierska 2011, p. 118), in line with the fundamental ontological observation that "every "we" or political

\footnotetext{
3 Mouffe introduced the terminological distinction between 'agonism' and 'antagonism' in 1995 (Jezierska 2011, pp. 127-128; cf. Mouffe 1995). In this paper, I refer to conflicts as 'antagonisms' but to Mouffe's theory as an 'agonistic' one.
} 
collectivity (...) depends upon a "they" or "constitutive outside" by which the collective defines itself' (Breen 2009, p. 136; cf. Mouffe 1993, pp. 114, 143; Mouffe 2000, pp. 99-100; Mouffe 2005, pp. 15, 89).

Mouffe's emphasis on conflict as an ontological dimension of social being (McNay 2014, p. 67), and its ontological primacy towards the social (Yamamoto 2017 , p. 390) on one hand, and the need of its institutional and rule-based ramification ('proceduralism' or 'sublimation'), on the other, as well as the focus on ongoingness of decision-making processes within the polity (cf. Smoleński 2012, p. 78) make her theory attractive as a vantage point allowing for a critical reconsideration of the phenomenon of adjudication. After all, adjudication (and law in general) is precisely about conflict (Kukovec 2014, p. 136), which is articulated within the framework of rule-based institutional arrangements-the 'common symbolic space' of the courtroom (Bator 2020, p. 26). Adjudication leads to the on-going production and evolution of case-law, which is (just like 'democratic agonistic play') 'permanently contingent' (Menga 2017, p. 539), being 'an essentially unstable discursive structure' (Mouffe 2018, p. 90). In her theory, Mouffe 'strictly maintains [the] distinction between the notions of the political as ontological and of politics as ontic' (Yamamoto 2017, p. 391) —in terms of legal theory this translates into the ontological dimension of conflict (antagonism), which is then articulated as litigation in the ontic dimension of legal institutions and procedures. This brings us to the question of the juridical and its relationship to the political. I will elaborate it in the next section paying particular attention to the place of a judicial decision which is a span between those two spaces.

\section{Adjudication at the Crossroads of the Juridical and Political}

A judicial decision-even if in its dimension of singularity (Derrida 1992, p. 23) it does contain an element of sovereignty (Fusco 2017, p. 134)—nonetheless never appears fully as a self-standing and self-legitimising 'event', entirely detached from the context of earlier case-law (cf. Fish 1982; Douzinas and Gearey 2005, p. 170) and from the lex scripta, a feature of adjudication which is congruent with Mouffe's focus on continuity and process pace Schmitt's decisionism (Smoleński 2012, pp. 78-79). Adjudication is inherently grounded in the historicity of the ius and lex which precede it; its 'time is synchronic' (Douzinas and Gearey 2005, p. 173). Even an entirely novel reinterpretation of the law is always already inscribed into previous interpretations. However, in congruence with Mouffe's vision of radical democracy, adjudication (and the underlying phenomenon of legal interpretation) is characterised by 'structural undecidability, or radical contingency' (Jezierska 2011, p. 110).

The question concerning the relations between judicial decision-making and the political is part and parcel of a broader question of the relation between 'the juridical' and the political. By 'the juridical' I understand here the entirety of the social institution (Berger and Luckmann 1991, pp. 70-84) of law, which I consider as a form of articulation of the political (of social conflicts) parallel to politics (and, as politics, part of the social understood as 'the realm of sedimented practices' [Mouffe 2005 , p. 17]). The juridical as a social institution is characterised by its distinct set 
of bodies (predominantly courts) and procedures, operated by the epistemic community of lawyers (Mańko 2020b, p. 38). It is informed by legal traditions and mentalities, and as such it is a field of social being distinct from politics, the economy or religion. The professional culture of lawyers differs from other professional cultures (Mercescu 2018, pp. 185-186). 'The law', a set of rules and principles (codified or distilled from precedent), is embedded within the juridical, and cannot function outside it; its application and development depend on its operation by the community of lawyers, the 'legal intelligentsia' (cf. Kennedy 1997, p. 41). The juridical, in this sense, is essentially the 'language of institutionalised practice' (Kozak 2010, p. 147) of the legal intelligentsia. The juridical is distinct from politics because it functions according to different principles of decision-making (democratic voting vs. legal reasoning), different procedures (parliamentary debate vs. court hearing), and different outcomes (political decisions vs. judgments in individual cases). Yet it occupies an analogous position vis-à-vis the political, in that it also serves as a forum for articulation of the same social conflicts, although using a different language- the language of legal rights and legal duties, legal subjects and legal objects, etc., purportedly ideology-free, depoliticised and neutralised (cf. Fusco \& Zivanaris 2021, pp. 3-5). The juridical, through its distinct approach (work with authoritative texts, the application of legal reasoning) seeks to operate closure, i.e. the ex ante predictability and determinacy of the outcomes of cases, purportedly based on pre-existing factors (codes, precedents or custom). However, this closure is never full or perfect-this extant, remaining part of the political which escapes the attempt at closure is conceptualised as the question of 'indeterminacy', which I discuss later on.

The process of adjudication is a privileged site of interaction between the juridical and the political, the site in which social conflicts (the political) are articulated in their individual instantiations using the language and logic of the juridical. As a result, the judge plays a double function: on one hand, that of a jurist, embedded in the institutional imperatives of the juridical (applying codes or precedents, using legal reasoning), and on the other hand, that of a decision-maker in the field of social antagonisms. Regardless of the refinement of legal reasoning, its outcome is always a blunt intervention of the juridical into the non-juridical, affecting someone's freedom, property, dignity, sometimes even one's life (cf. Cover 1986). A judgment is, therefore, always already a 'juridico-political decision', a decision which impacts upon the political (an antagonism) but intellectually and culturally stems from the juridical and is fully cloaked in historically and locally contingent legal form. True, deciding on social conflicts is at the roots of the juridical. 'A dispute, a conflict of interest, elicits the form of law, the legal superstructure', wrote Pashukanis (1997, p. 67), adding that law 'historically emerged from controversy, i.e. from a claim [an action], and only thereafter did it overlap with the earlier (purely economic or factual) relationship' (ibid.). Indeed, the political as the dimension of inherent conflict propels not only democratic politics (Jezierska 2011, p. 127), but also the juridical. Walter Benjamin was particularly sensitive to the intimate link between law and violence when he observed that '[w]hen the consciousness of the latent presence of violence in a legal institution disappears, the institution falls into decay' (Benjamin 1978, p. 288). This sits well with the Marxist insight that law is 'the continuation of domination by other means' (Cercel 2018, p. 95). 


\section{'Relative Sovereignty' of the Judge's Decision: the Question of (In-) Determinacy}

Whereas many, if not most, judicial decisions are 'political' ones in the sense used above, not all of them are equally creative in the sense of being the product of a sovereign gesture of laying down new rules for the case at hand, rather than applying well-established interpretations of legislation or existing precedent. The question of judicial discretion, and therefore the judge's freedom to take a 'sovereign' politico-judicial decision, is a question of degree, rather than one of an all-or-nothing distinction. As Kennedy put it, judges function within law as a 'medium' which, on one hand, empowers them but, on the other hand, limits them (1997, pp. 158-160; 2008, pp. 6-7, 18-19). 'To say that the interpretation of the rule was determinate' — writes Kennedy — 'is only to say that (...) the interpreter was unable to accomplish the strategically desired re-interpretation' (2008, p. 160). The possibility of reaching a strategically (politically, ideologically) desired re-interpretation is, in his view, 'a function of time, strategy, skill and the "intrinsic" or essential or "objective" or "real" attributes of the rule one is trying to change' (Kennedy 2008, p. 160). Also other factors are at play, especially the position of the judge in the court hierarchy (it is more likely for a supreme court judge to impose a new interpretation than for a lowest-instance judge), the character of the facts of the case (Kennedy 2008, p. 160), and the degree to which the existing legal interpretation is 'patently unjust' on the facts, as well as the conformity of the existing interpretation and expectations of the public, the hegemonic ideology or desires of the other branches of government (pushing a new interpretation will be easier if that is expected by the public, the government and consistent with the hegemonic ideology) (cf. Beck 2012, pp. 446-448).

The quantity of 'legal work' (Kennedy 1997, pp. 161-165) that a judge needs to do in order to reach a desired outcome is one thing, but external and objective factors, such as notably the judge's hierarchical position and the general expectations on what the law 'should say' also weigh heavily on the scope of her actual scope of discretion. As a rule of thumb, courts which are supreme in their respective hierarchies (such as constitutional courts or supreme courts) and supranational courts, well-known for their highly creative and practically unrestrained law-making, can be said to enjoy such broad discretion much more effortlessly than other courts.

In a sense, any judicial decision is at the same time sovereign and bound. Every decision is sovereign due to the unsurmountable gap between the rule and its application, the (general) legal norm and the (individual) judgment (Schmitt 2005, p. 31; Derrida 1992, pp. 22-24; Agamben 1998, pp. 20-21; Agamben 2005, pp. 31, 36, 39-40; cf. Fusco 2017, p. 134). Of course, the judge may have a subjective feeling that she is taking a bound decision, simply following the 'letter of the law' or binding precedent, but this only means that she (more or less consciously) foreclose the very possibility of delivering a different decision, reinterpreting the written law (e.g. in the light of general principles), distinguishing precedent or otherwise using some other interpretive device allowing her, at least 
potentially, to make an 'unbound' decision. Ultimately, therefore, every single judicial decision is a sovereign one because, at the very least, it is a decision not to depart from an established interpretation-which, in itself, is always already a decision. It is also sovereign precisely because despite the possible self-delusion of the judge and the entire ideology of 'application of law',

in the case of law, the application of a norm is in no way contained within the norm and cannot be derived from it; otherwise, there would have been no need to create the grand edifice of procedural law. Just as between language and world, so between the norm and its application there is no internal nexus that allows one to be derived immediately from the other. (Agamben 2005, p. 40). ${ }^{4}$

There is a powerful force at work in this infinite space open between the general norm (be it a rule in the code or a ratio decidendi) and the individual judicial decision-it is ideology, which I discuss in the next section.

\section{Ideology and Adjudication}

If, following Mouffe, we admit that the political 'is linked to the acts of hegemonic institution' (Mouffe 2005, p. 17), the importance of ideology ${ }^{5}$ in the making of 'politico-judicial decisions' by judges becomes obvious, especially that, as Costas Douzinas points out, law 'is first and foremost an ideological practice' (Douzinas 2014, p. 188). The possible relationships between the judicial office and the political have been typified by Duncan Kennedy through such figures as 'activist judges', 'difference-splitting judges', or 'bipolar judges' (Kennedy 1997, pp. 182-186), as well as 'centrists' (Kennedy 2008, pp. 184-186), 'cause lawyers' and 'cause lawyers in denial' (Kennedy 2015, pp. 114-115). If we add also the figure of a simply cynical judge, strangely overlooked by Kennedy (Mańko 2018, pp. 208-209), we probably arrive at a fairly comprehensive panorama of possible judicial approaches to ideology. Contrary to Kennedy, however, I do not think that ideologies should be limited only to two-liberalism and conservatism as he suggests (1997, p. 39), but rather adjudication should be perceived as a field of interplay of a whole array of ideologies, including especially neoliberalism, (religious) conservatism, nationalism, but also socialism, socialist democracy or communism (e.g. Freeden and Steers 2013), corresponding roughly to 'ethico-political principles' in Mouffe's understanding, such as 'liberal-conservative, social-democratic, neo-liberal, radical-democratic'

\footnotetext{
${ }^{4}$ Modified translation.

5 Understood as a "universalization project of an ideological intelligentsia that sees itself as acting "for" a group with interests in conflict with those of other groups' (Kennedy 1997, p. 39), and at the same time also as 'a system (...) of representations (images, myths, ideas or concepts, depending on the case) endowed with a historical existence and role within a given society' (Althusser 2005, p. 231) and as 'a fantasy construction which serves as a support for our "reality" itself: an "illusion" which structures our effective, real social relations and thereby masks some insupportable, real, impossible kernel' (Žižek 2008[1989], p. 45). As such, ideology 'is a structure essential to the historical life of societies' (Althusser 2005 , p. 232), even if it is essentially contested (Kennedy 1997, p. 42).
} 
(Mouffe 2000, pp. 103-104). Each ideology, with its ethico-political principles, "proposes its own interpretation of the "common good", and tries to implement a different form of hegemony' (Mouffe 2000, p. 104). This implementation takes places also within the sphere of the juridical-through legislation and adjudication, the latter comprising legal interpretation.

The link between the political and ideology is to be found in the person of the interpreter and the interpretive community to which she belongs. This is because legal interpreters do not exist in a void but rather they all 'occupy a determined place in the structure of social conflicts which constitute the political' (Eakomy 2018, p. 26). In fact, '[b]roader social antagonisms finding their place in specific court proceedings undertake the form of debates on the "proper" interpretation of legal texts that are to shape the basis for the decision in the proceedings' (Eakomy 2019, p. 51). Legal interpretation without any ideological influence is a fiction which has never existed and will never exist (Fish 1989, p. 518). But this inherent nexus between law and ideology goes much deeper, touching upon the very ontology of the law as something which 'emerges through re-doubling of reality and identification with its spectral, normatively reconstituted counterpart' (Tacik 2020, p. 15).

Quite apart from the influences of other institutional sub-worlds, such as those of politics, economy or religion, which can externally impact upon the outcome of interpretative decisions, and from the internal imperatives of the juridical, especially the legal community (cf. Fish 1982, p. 562), judges are significantly and effectively constrained in their readings of legal texts by the hegemonic ideology. If certain legal interpretations are more prevalent and treated as 'objective' by a given legal community, this is because of a shared 'cognitive structure of the members of a given interpretive community' (Łakomy 2018, p. 33). This 'cognitive structure', is, arguably, determined mainly by (the hegemonic) ideology, precisely because ideology is a 'frame' which we superimpose on raw facts of social reality in order to understand it and interpret it (Žižek 2008, p. 145). Whether and to what extent the law operates closure or leaves an opening depends, therefore, in the last instance not so much on the legal materials (legislation, case-law) but on the ideological light which is cast upon them. Doubtless, the ideological impact upon adjudication need not be the result of a judge's conscious decision (as in the case of Kennedy's figure of the 'activist judge'). More often than not, ideology impacts judicial decision-making unconsciously. This is because the hegemonic ideology 'represents common sense understanding of the world and elementary principles of morality', 'directs the judicial sense of justice and provides it with a sense of the relative weight of conflicting arguments' (Collins 1988, p. 67). Therefore judges, when engaged in legal interpretation, consciously think that what they are cloaking in legal form is rather 'common sense' or 'elementary principles of morality', rather than ideological premises (ibid, p. 73). In some legal cultures there are even specific juridical figures which induce judges into following the hegemonic ideology, such as 'reasonableness' in the Common Law, 'good morals' and 'good faith' in the Germanic tradition, the bon père de famille in French law, the 'rational law-maker' in Polish legal culture (cf. Borowicz 2009, pp. 9-13).

Of course, as Althusser already noted, 'those who are in ideology believe themselves by definition outside ideology: one of the effects of ideology is the 
practical denegation of the ideological character of ideology by ideology' (2014, pp. 264-265). In contrast to the external impact of non-juridical factors, such as the demands of the executive or 'the markets', ideological influence upon adjudication usually operates more subtly, often unconsciously. Nonetheless, judges who claim they are 'ideology free' are either acting in bad faith, or are simply 'in denial' in the psychoanalytical sense (Kennedy 2008, p. 163). Although the degree to which ideology plays a crucial role in judicial decision-making varies from case to case, one can safely say that it is highest in those instances when judges face interpretive dilemmas, especially when requested to apply balancing of rights and/or principles, proportionality tests or to interpret open norms (general clauses) (Kennedy 2015). Adjudication cannot, therefore, be treated as an 'ideology-free' phenomenon; to the contrary, it is permeated by ideology and predetermined by it. Judges, whether they want it or not and whether they realise it or not are ideological actors and it is precisely in ideology that they find - oft unconsciously - the muster of 'normal' social relationships that they impose upon the antagonisms they decide. In the next section I look more closely at those antagonisms and propose a typology.

\section{Social Antagonism As Object of the Judge's Decision}

Following Mouffe, in constructing the notion of an (ant)agonism for the purposes of a critical theory of adjudication there is 'need to take account of a variety of heterogeneous struggles, instead of envisaging the collective political subject exclusively in terms of "class" (Mouffe 2018, p. 82; cf. Jezierska 2011, p. 128). This does not mean, of course, that economic antagonisms should be eliminated from the scope of purview; however, they should not be the only antagonisms that are analysed. It is crucial to remember that 'the social agent is constituted by an ensemble of "discursive positions" that can be never be fixed in a closed system of differences', making the 'identity of such a multiple and contradictory subject (...) always contingent, precarious, temporarily fixed at the intersection of those discourses and dependent on specific forms of identification' (Mouffe 2018, pp. 88-89). This applies to identities and subjectivities constructed within various legal discourses.

Keeping this in mind, I do not endeavour to propose a closed list or typology of antagonisms that can enter into the purview of adjudication; the scope of the latter is a function of actual conflicts in society (with new ones emerging), on one hand, and the juridification of social life, on the other. However, it seems possible to put forward a tentative typology of such antagonisms: I propose to divide them into economic, ideological and socio-political ones. By economic antagonisms I understand conflicts concerning the division of labour, on one hand, and its effects (access to goods, services), on the other, as well as conflicts relating to the means of production and, more generally, access to various forms of property. Typical antagonisms include class conflicts where the working class is either identified directly as such (worker vs employer; trade union $v s$ business), or indirectly through various contractual arrangements outside the workplace (e.g. tenant vs landlord; consumer vs trader; client vs bank). Of course, the identities in question, such as that of a consumer, are not monoliths; some legal solutions may benefit middle-class 'circumspect' 
consumers at the expense of poor ones, whilst others may truly benefit the actually disadvantaged ones (cf. Micklitz 2020, pp. 219, 222). A broader look upon economic antagonisms will reveal also conflicts relating to access to culture (e.g., consumer of culture $v s$ holder of intellectual property rights) and various forms of socio-cultural production (e.g. user of social media vs social media business). As the two latter examples reveal, changes in socio-economic reality generate new conflicts which cannot be predefined once and for all. In juridical terms, economic conflicts will be usually framed as civil lawsuits, often contractual ones (e.g. concerning the interpretation of a labour contract, consumer sales contract, or loan agreement), but also as tort cases or even criminal cases (e.g. in the area of intellectual property). In ideological terms, such conflicts will be articulated usually through the opposition between social-democratic ideologies, on one hand, and liberal or neo-liberal ones, on the other.

The second group of antagonisms, which I refer to as ideological, pertain to broadly defined moral questions which enter into the sphere of juridification (cf. Paździora 2019, p. 127). Ideological conflicts will usually antagonise liberals/progressives $v s$ conservatives/traditionalists in various areas, including secularity of the state, reproduction rights, equal access to marriage, limits of free speech (e.g. blasphemy laws, protection of artistic freedom). In procedural terms, cases of this kind often come in the form of criminal law: the individual representing the liberal/ progressive side (a woman seeking abortion or an artist seeking freedom) will often appear as the accused, and have against him or her the machine of the state (prosecution). However, ideological conflicts also appear in the form of civil lawsuits (e.g. defamation cases) or administrative disputes (e.g. regarding religious symbols in public spaces or regarding equal access to marriage). More often than in the first category, the stance of the liberal/progressive side of the antagonism is likely to be framed in terms of fundamental (human) rights (e.g. right to marriage; right to privacy; right to freedom of expression). In ideological terms, such conflicts will be articulated as a contest for hegemony between liberal or social-democratic ideologies, on one hand, and conservative/religious ideologies, on the other.

Finally, the third category, which could be dubbed socio-political or statusrelated, intends to encompass all that is not clearly and predominantly economic nor purely ideological. This category covers, first of all, conflicts relating to membership in the political community and one's status within it. Examples include migration and refugee law, cases concerning linguistic rights of ethnic minorities, or cases concerning nationality. In juridical and procedural terms, such cases will most typically appear in the guise of administrative law with the member of the vulnerable or subaltern group facing the hostile majority personified by the organs of the state. But in the deeper (ontological) dimension of the political, such cases (e.g. concerning access to territory or to citizenship) are actually based on an antagonism between the subaltern group (e.g. a migrant community or a group of refugees seeking protection), on one hand, and the host community. The ideological articulation of such conflicts will usually involve conservative and nationalist ideologies, on one hand, and social-democratic, or radical democratic ideologies on the other.

The above typology does not, of course, mean that in one single instance of litigation only one identity can be involved; to the contrary, the three dimensions can 
intertwine, even in one case. What is crucial, is that these antagonisms refer to "concrete human groups' (Mouffe 1993, p. 113), brought together by common economic, ideological, or other collective interest which oppose them to other groups, holding an opposing economic, ideological or other collective interest. The formation of opposing identities - such as workers $v s$ employers or consumers $v s$ traders-rests on a 'we vs they' distinction (Jones 2014, p. 15), which describes very well the reality of litigation. What is at work in the forming of such identities is, of course, a chain of equivalences i.e. the 'process of abstracting from the particular interests and a search for a higher level, universal principle' (Jezierska 2011, p. 117). Workers, consumers, tenants, migrants, women or minorities each have particular interests, depending on various factors, and each case involving them is unique and different. However, by focusing on establishing a chain of equivalences, critical theory of adjudication can change the perspective of perceiving case-law, and draw attention to what litigants belonging to such a group have in common, and focusing on litigation in its agonistic dimension. Because 'chains of equivalence are intrinsically linked to the moment of negativity' (Jezierska 2011, p. 117), the formation of identities relevant for the juridical, such as consumers, workers, migrants, or minority members, necessarily involves the axis of opposition towards a different group with which a conflict over the outcome of legal interpretation is at stake. Consumers cannot be defined without a reference to traders; workers-without a reference to employers; minority members-without a reference to a majority; and moral progressives/liberals-without a reference to traditionalists/conservatists (cf. Paździora 2019, p. 128). The constitutive moment of a juridical identity is therefore in the conflict of interest with a 'shared antagonist' (Jezierska 2011, p. 118).

In this perspective, individual judicial decisions in conflicts between representatives of the antagonistic groups can be viewed as steps, more or less significant, more or less decisive, in their on-going struggle, as 'temporary respites in an ongoing confrontation' (Mouffe 1999, p. 755). For a given judicial decision to directly affect a collective antagonism it need not be framed in strictly legal terms as collective litigation (e.g. as a class action or representative action); it is sufficient that its outcome, either legally (binding precedent) or factually (persuasive precedent, gradual evolution of a line of case-law) has an impact upon such collective interests. Decisions of supreme, constitutional and supranational courts, if they are concerned with any identifiable collective interests, due to the authority of their case-law, per se impact the entire class of legal subjects belonging to the same collectivity (e.g. all bank clients, all employees, all women wishing to terminate pregnancy etc.). This does not mean that decisions of lower courts lack a significance from the perspective of the agonistic theory of adjudication. However, as with the question of the sovereign vs. bound character of a judicial decision, the impact of a judicial decision upon an antagonism is also a question of degree rather than an all-or-nothing question. Decisions of lower courts, even if their direct juridical impact is limited only to the parties to the litigation (i.e. they do not constitute precedent, neither de jure nor even de facto), nonetheless contribute to the development of a certain line of case-law, a practice of deciding cases of the same or similar kind (at least in the same court, or by the same judge). In this sense, each and every decision even of a court of lowest instance still contributes to the way in which law shapes a given antagonism in its 
collective dimension. The same judge at the court or her colleagues dealing with similar cases will be naturally inclined to follow the earlier decision taken at the same court: even if legally speaking it is not a binding precedent, it can nonetheless give rise to a habit of deciding similar cases similarly, and therefore gain significance extending beyond the original, individual litigation at its origin.

\section{Operationalising the Theory, or on the Importance of Critical Case-Notes}

What differentiates critical legal theory from other forms of jurisprudence is not only the hermeneutic of suspicion, urging to question existing narratives' legitimating power, but also its emancipatory goal (Kennedy 1997, p. 5; cf. Horkheimer 1999[1937]; Douzinas and Gearey 2005, pp. 241-244). If the emancipatory goalthe 'attempts to redress instances of (...) inequality, injustice, exclusion, marginalization, subordination, and violence' (Fossen 2008, p. 385) —is to be taken seriously, critical legal theory must build direct bridges into the domain of legal practice. Each and every day courts of law around the world hand down judgments which inflict violence: divide wealth, deprive human beings of liberty or, in some countries, even of life. Adjudication takes place 'in a field of pain and death' and judges 'frequently leave behind victims whose lives have been torn apart by these organized, social practices of violence' (Cover 1986, p. 1601). Critical jurists can, of course, join the struggle on the side of the oppressed by engaging in the practice of critical lawyering, thereby becoming 'cause lawyers', who seek to impose-as lawyers representing parties in court - a more emancipatory and less oppressive legal interpretation (Kennedy 2015). But also the critical legal scholar can participate in the struggle for emancipation by engaging into a genuine dialogue with the courts, a dialogue conducted in doctrinal articles and in particular through the genre of case-notes.

In what follows, I roll out a proposal on how such case-notes could be structured, not so much in terms of their form (the order of the text), but above all in terms of the formulation of the research questions and the aspects of the judgment (in its broadest context) that should be dealt with. My proposal is structured along six 'steps' which form a kind of 'research protocol' that could be followed by critical jurists when analysing and critiquing judgments (cf. Mańko 2020a, pp. 99-101). Its main aim is to take into account, in the broadest possible extent, the socio-economic and ideological ramifications of the interpretive decision taken by the judge in the commented cases.

The first step of the proposed analysis is the identification of the conflict (social antagonism) at stake. The identity of the parties to the litigation may be an indication thereof, but it is not a decisive one. It is necessary to view the dispute before a court in the entirety of its social, political, economic and ideological context, in line with what I wrote above about the judge's decision affecting social conflicts. Regardless whether the judge herself is capable of adopting such a point of view, it is a task of the critical jurist to venture beyond the judge's internal vantage point.

Secondly, once the essence and content of all the antagonisms at stake have been identified, it becomes necessary to ascertain-as part of the second step of 
analysis - what legal materials a court could find appropriate to decide the case. The character of such materials will depend on the given court and the legal culture within which it acts; in any event, only materials which, in a given legal culture are treated as legally relevant (binding or persuasive authority) are at stake here.

In the third step of the analysis, having determined what legal materials are at stake, it is necessary to evaluate their possible interpretations, i.e. alternative interpretive decisions that the court could have reached. Adopting, in line with the assumptions of critical legal theory, the theses of hermeneutic universalism, I assume that no legal norm, be it a constitutional principle, a legislative rule, or a precedent, may be simply 'applied' to a given set of facts without its interpretation (Mańko and Łakomy 2018, pp. 480-482). Such an approach would simply amount to a form of 'lawyers' camouflage' aimed at concealing the true stakes behind a given interpretation (Sulikowski 2016, p. 256). Assuming that interpretation is always necessary and often contested, I propose to order the possible results of the interpretation on an axis extended from the maximisation of interests of group A to the maximisation of the interests of group B (e.g. workers-employers; consumers-traders; progressive liberals_religious conservatists). This proposed approach is directly inspired by the 'individualism' - 'altruism' axis proposed some time ago by Duncan Kennedy (1976), and later developed by Martijn Hesselink (2006) as the 'autonomy' - 'solidarity' axis. For instance, if the case at hand is concerned with the interpretation of consumer law, the possible ways of understanding a given rule could be placed on an axis extending from the most pro-consumer interpretation to the most pro-business interpretation, and in a labour case-from the most proworker interpretation to the most pro-employer interpretation. I assume that there can be no 'neutral' position on the axis, no 'perfect compromise', but that always the position between the two poles benefits more to one or to the other side (Mańko 2020a, p. 101 pace Mak 2008, pp. 212-213; cf. Łakomy 2020, p. 87).

In the subsequent, fourth step, it is necessary to determine which of the possible interpretive options was chosen by the court, i.e. how can the court's decision be placed on the axis of interests of the two antagonistic groups.

As a fifth step of the analysis, the judgment-seen as a decision of choosing one interpretation from among two or more others- has to be analysed in light of the existing ideologies, both the hegemonic one (for instance, neoliberalism) and others, competing for hegemony (for instance, socialism, or social democracy, or some other counter-hegemonic ideological project). This step is crucial to understand the judgment, but tactically it would probably be advisable to avoid elaborating on it too much in a case-note destined for a mainstream legal journal (cf. Kennedy 2015, p. 131; Mańko 2018, p. 206).

A further analysis of the judgment - the sixth step of the analysis - can indicate that the interpretive options more favourable to e.g. consumers or employees or minorities were actually backed by additional strictly juridical arguments, such as linguistic, systemic, functional or those linked to constitutional values, etc. A key element of the proposed approach is that the judicial decision is analysed above all as a political decision on the contested interests of subjectivities which are in conflict (e.g. traders and consumers, employees and employers, minorities and majorities, migrants and xenophobes) with the important assumption that there are possible 
legal arguments for other ways of interpreting the legal norms applicable in the case. The judge's decision in the analysed case (and an entire line of case-law) is, therefore, understood - just like the social order as such — as a 'temporary and precarious articulation of hegemonic practices whose aim is to establish order in a context of contingency' (Mouffe 2018, p. 88). This way, judicial decision-making is inscribed into the notion of hegemonic practices 'through which a given order is created and the meaning of social institutions is fixed' (Mouffe 2018, p. 88).

What is crucial in the proposed modus of analysis is to emphasise that ' $\mathrm{t}]$ hings could always have been otherwise and every order is predicated on the exclusion of other possibilities' (Mouffe 2018, p. 88). Due to the structural undecidability of the juridical, 'any decision could have been otherwise' (Jezierska 2011, p. 111). In fact, "[f]or a choice to be called a "decision", it must have been taken in the undecidable. (...) This means that there must have been alternatives, i.e., multiple options and consequently-exclusions' ibid. The aim of the method of critical analysis of case-law, espoused here, lies in emphasising those alternatives, on the assumption that 'once the decision is made, it still has a remainder, a trace of undecidability in it' ibid. The task of the critical commentator of case-law is to question the decision precisely by evoking those alternatives and evaluating them, one by one, in the light of emancipatory agonistic theory. This approach is directly opposed to legal formalism understood as the view that adjudication 'aims to find a pre-assumed answer to a legal question using legal methods, canons, and forms of argumentation' (Paździora 2019, p. 132). For judges, belonging usually to the elite of a society, sympathising with the subaltern and oppressed groups may be a challenge (Pichlak 2020, pp. 119-120); critical case notes along the lines proposed here could help them see the alternatives which they otherwise might not even notice in their professional habitus (cf. Bator 2020, p. 23).

Of course, for such an analysis to make sense within the limits of legal discourse (as opposed to political or philosophical discourse), a generally 'realistic' approach to the analysis ought to be maintained, especially with regard to the identification of the legal materials which, under a given legal culture, could be applied in the case and to the application of methods of interpretation accepted in a given legal culture (Mańko 2020a, p. 101; cf. Kaczmarek 2019, p. 218). Using those materials and methods in a creative way - through a great deal of 'legal work' — can help to build alternatives which, to mainstream lawyers, could seem prima facie outlandish. But since they are constructed with otherwise recognised building blocks (legal materials and legal methods accepted in a given legal culture), they can become viable interpretive alternatives.

\section{Conclusion}

The proposed agonistic theory of adjudication, advanced in this paper, challenges liberal legal and political theories which 'display a tendency to downplay the role of social, economic and political conflict' (Kochi 2014, p. 128). The theoretical assumptions and modes of critical analysis put forward here aim to feed into what Robin West refers to as 'normative jurisprudence' (West 2011), i.e. a discourse about 
what the law should be, in the light of a certain conception of justice, as opposed not only to purely descriptive and analytical accounts of the law, but also to 'faux-normative' discourse (ibid., pp. 181-190), based on historical arguments or arguments of what the law allegedly 'really is'. By focusing on the sphere of the judge's 'sovereign' decision, where she is faced with an authentic choice between possible legal interpretations, the method of critique espoused here draws attention to the very moment of genuine judicial law-making which is not different, in terms of producing new legal rules, from legislative law-making. However, in contrast with the fauxnormative method, rightly criticised by Robin West and earlier by Schlag (1990, 1991, 2009) and Kahn (1999), the proposed approach focuses not on producing arguments styled as 'statements of law' (West 2011, p. 184), constructed-more or less bona fide - as allegedly restating the law as it supposedly is (cf. Kennedy 2015, pp. 114-115), but rather, through focusing on cracks in the fabric of law's purported certainty, seeks to address those areas where the law is still to be determined or is in statu nascendi or where settled law is being disrupted through topoi of a-legality (cf. Lindahl 2009; 2013), including through legal work performed by the ideologically motivated judge (cf. Kennedy 1997). The aim is not so much to completely replace the commonplace liberal-legalistic approach of filling such gaps through deduction/ induction (Kennedy 2015, pp. 92-95), coherence-focused reasoning, including analogy (MacCormick 1978, pp. 119-128, 152-194; Beck 2012, pp. 120-125, 130) or historical argumentation, but rather to supplement them (Bator 2020, p. 22), to give them an ethical 'soul' in the form of antagonism-aware, justice-focused argumentation in the spirit of "'reasonable" judicial assertiveness' (Aseeva 2021, p. 163). Law without justice is like a body without a soul (Douzinas 2000, p. vii), and therefore employing the rich array of legal argumentation without an overarching ethical guiding principle will end up generating, at best, a series of haphazard results, as in Kennedy's model of bipolar judges and difference splitters (Kennedy 1997, pp. 184-186; 2008, p. 163). Just like, within the political, democracy is always 'to come' (Mouffe 1993, p. 8; 2000, p. 137), so too, within the juridical, is justice.

Agonistic theory of adjudication focuses on the effects of a given judicial decision for a given subjectivity/collectivity and its interests. This is a direct consequence of establishing a short-circuit between the external (normatively justice-focused) point of view with the internal (legal method-focused) one (Bator 2020, p. 28). What could prima facie seem to be an inherent limitation of the proposed approach ("why consider oneself bound by the culturally accepted methods of interpretation in a given jurisdiction?'), is at the same time a strength of the approach, for it allows to play with those arguments which are considered 'valid' or 'persuasive' in a given legal culture, instead of trumping them altogether by sheer justice-focused normative claims about what the law should be. The aim of the theory I put forward here is to make an attempt at unblocking judicial habiti which, rather than existing interpretive tools, are barrier to pursuing a more ethically-oriented jurisprudence (Bator 2020, p. 23).

Perceiving judgments as politico-judicial decisions, essentially boiling down to making a singular choice out of the plural interpretive possibilities provided in a given case by legal culture, reminds us of the radical contingency of the juridical, and enables one to pose the question of justice and injustice, thereby contributing to 
the task of critical jurisprudence understood as continuously 'disrupting the law in the name of justice' and 'reminding the law of its inescapable violence' (Douzinas and Gearey 2005, p. 172), committed not only in the individual dimension (vis-àvis the defeated litigant), but also in a structural, collective dimension of the social antagonism. By emphasising the actual winners and losers of judicial decisions (cf. Bartl 2020, p. 253), and bringing to the fore alternative solutions to cases, critical lawyers can achieve the goal of destabilising existing hegemonies in order to speak for the economically, symbolically and politically dominated and excluded.

Acknowledgments I would like to thank Anna Aseeva, Cosmin Cercel, Gian Giacomo Fusco, Jakub Łakomy, Alexandra Mercescu, and Przemysław Tacik for reading and commenting on this paper at the various stages of its drafting and revision. I would also like to thank the anonymous peer reviewers for their constructive critique. The present paper presents exclusively my personal views and should not be attributed to any institution.

Open Access This article is licensed under a Creative Commons Attribution 4.0 International License, which permits use, sharing, adaptation, distribution and reproduction in any medium or format, as long as you give appropriate credit to the original author(s) and the source, provide a link to the Creative Commons licence, and indicate if changes were made. The images or other third party material in this article are included in the article's Creative Commons licence, unless indicated otherwise in a credit line to the material. If material is not included in the article's Creative Commons licence and your intended use is not permitted by statutory regulation or exceeds the permitted use, you will need to obtain permission directly from the copyright holder. To view a copy of this licence, visit http://creativecommons.org/licen ses/by/4.0/.

\section{References}

Agamben, Giorgio. 1998. Homo sacer. Sovereign power and bare life. Stanford: Stanford University Press.

Agamben, Giorgio. 2005. State of exception. Chicago/London: University of Chicago Press.

Althusser, Louis. 2005. For Marx. London/New York: Verso.

Althusser, Louis. 2014. On the reproduction of capitalism: Ideology and ideological state apparatuses. London/New York: Verso.

Aseeva, Anna. 2021. From corporate social responsibility to corporate social liability: A socio-legal study of corporate liability in global value chains. Oxford/New York: Hart.

Bartl, Marija. 2020. Socio-economic imaginaries and European private law. In The law of political economy: Transformation in the function of law, ed. Poul F. Kjaer, 228-253. Cambridge: Cambridge University Press.

Bator, Andrzej. 2020. Law and jurisprudence in the face of conflict: Between neutrality and the political. Krytyka Prawa/Critique of Law 12 (3): 7-31.

Beck, Gunnar. 2012. The legal reasoning of the Court of Justice of the EU. Oxford: Hart Publishing.

Benjamin, Walter. 1978. Critique of violence. In Reflections: Essays, aphorisms, autobiographical writings, ed. Walter Benjamin. New York: Schocken Books.

Berger, Peter L. and Thomas Luckmann. 1991. The social construction of reality: A treatise in the sociology of knowledge. London: Penguin.

Borowicz, Jacek. 2009. Argument interpretacyjny odwołujący się do woli rzeczywistego prawodawcy. Studia Prawno-Ekonomiczne 79: 9-28.

Breen, Keith. 2009. Agonism, antagonism and the necessity of care. In Law and agonistic politics, 133146. Ed. Andrew Schaap. Farnham: Ashgate.

Cercel, Cosmin. 2018. Towards a jurisprudence of state communism: Law and the failure of revolution. London: Routledge.

Collins, Hugh. 1988[1982]. Marxism and law. Oxford: Oxford University Press. 
Cover, Robert. 1986. Violence and the word. Yale Law Journal 95: 1601-1629.

Monteiro Crespo de Almeida, Leonardo. 2020. Direitos fundamentais e a democracia agonística: considerações jurídicas sobre a teoria política de Chantal Mouffe. Revista Direito e Práxis 11 (2): 944-970.

Derrida, Jacques. 1992. The force of law: The 'mystical foundation of authority.' In Deconstruction and the possibility of justice, ed. D. Cornell, et al., 3-67. New York: Routledge.

Douzinas, Costas. 2000. The end of human rights. Critical legal thought at the turn of the century. Oxford: Hart Publishing.

Douzinas, Costas. 2014. A short history of the British Critical Legal Conference or, the responsibility of the critic. Law and Critique 25: 187-198.

Douzinas, Costas, and Adam Gearey. 2005. Critical jurisprudence: The political philosophy of justice. Oxford: Hart Publishing.

Dyrberg, Torben Bech. 2009. The leftist fascination with Schmitt and the esoteric quality of 'the political.' Philosophy and Social Criticism 35 (6): 649-669.

Fish, Stanley. 1982. Working on the chain gang: Interpretation in the law and in literary criticism. Critical Inquiry 9 (1): 201-216.

Fish, Stanley. 1989. Doing what comes naturally: Change, rhetoric, and the practice of theory in literary and legal studies. Durham/London: Duke University Press.

Fossen, Thomas. 2008. Agonistic critiques of liberalism: Perfectionism and emancipation. Contemporary Political Theory 7 (4): 376-394.

Freeden, Michael, and Marc Stears, eds. 2013. The Oxford handbook of political ideologies. Oxford: Oxford University Press.

Fusco, Gian Giacomo. 2017. Normalising sovereignty: Reflections of Schmitt's notions of exception, decision and normality. Griffith Law Review 26 (1): 128-146.

Fusco, Gian Giacomo, and Michalis Zivanaris. 2021. The neutralisation of the political. Carl Schmitt and the depoliticisation of Europe. Journal of Contemporary European Studies. DOI: https://doi.org/10. 1080/14782804.2021.1873109

Gürsözlü, F. 2009. Debate: Agonism and deliberation-Recognizing the difference. Journal of Political Philosophy 17 (3): 356-368.

Hesselink, Martijn. 2006. The politics of a European civil code. In The politics of a European civil code, ed. M. Hesselink et al. The Hague: Kluwer.

Horkheimer, Max. 1999[1937]. Traditional and critical theory. In Critical theory: Selected essays, 188243. New York: Continuum Press.

Jezierska, Katarzyna. 2011. Radical democracy redux: Politics and subjectivity beyond Habermas and Mouffe. Örebro: Örebro University.

Jones, Matthew. 2014. Chantal Mouffe's agonistic project: Passions and participation. Parallax 20 (2): 14-30.

Kaczmarek, Przemysław. 2019. Three conceptions of individual agency in the world of institutions. In Paweł Jabłoński and Przemysław Kaczmarek, The limits of juristic power from the perspective of the Polish sociological tradition, trans. Stephen Dersley, 131-222. Berlin: Peter Lang.

Kahn, Paul. 1999. The cultural study of law: Reconstructing legal scholarship. Chicago: University of Chicago Press.

Kennedy, Duncan. 1976. Form and substance in private law adjudication. Harvard Law Review 89 (8): 1685-1778.

Kennedy, Duncan. 1997. A critique of adjudication (fin de siècle). Cambridge: Harvard University Press.

Kennedy, Duncan. 2001. The political stakes in 'merely technical' issues of contract law. European Review of Private Law 1: 7-28.

Kennedy, Duncan 2008. A left/phenomenological critique of the Hart/Kelsen theory of legal interpretation. In Legal reasoning: Collected essays. Aurora: Davies Group.

Kennedy, Duncan. 2015. The hermeneutic of suspicion in contemporary American legal thought. Law and Critique 25 (1): 91-139.

Knops, Andrew. 2007. Debate: Agonism as Deliberation - On Mouffe's Theory of Democracy. Journal of Political Philosophy 15: 115-126. https://doi.org/10.1111/j.1467-9760.2007.00267.x

Knops, Andrew. 2012. Integrating agonism with deliberation-Realising the benefits. Filozofija i Društvo 23 (4): 151-169.

Kochi, Tarik. 2014. Being, nothing, becoming: Hegel and the legal order. In New critical legal thinking: Law and the political, ed. Matthew Stone, Illan rua Wall, and Costas Douzinas, 128-144. Abingdon: Birkbeck Law Press/Routledge. 
Kozak, Artur. 2010. Myślenie analityczne w nauce prawa i praktyce prawniczej. Wrocław: Wydawnictwo Uniwersytetu Wrocławskiego.

Kukovec, Damjan. 2014. Hierarchies as law. Columbia Journal of European Law 21 (1): 131-193.

Laclau, Ernesto, and Chantal Mouffe. 2001. Hegemony and socialist strategy: Towards a radical democratic politics. London/New York: Verso.

Łakomy, Jakub. 2018. Polityczność (teorii) wykładni prawa: perspektywa neopragmatyzmu Stanleya Fisha. Archiwum Filozofi Prawa i Filozofi Społecznej 3: 24-37.

Łakomy, Jakub. 2019. Hermeneutic universalism: A post-analytical perspective on the political character of legal interpretation. In A post-analytical approach to philosophy and theory of law, ed. A. Bator and Z. Pulka, 39-56. Berlin: Peter Lang.

Łakomy, Jakub. 2020. Critical jurisprudence of Duncan Kennedy and the status of the theory of legal interpretation. Krytyka Prawa/Critique of Law 12 (3): 70-89.

Lindahl, Hans. 2009. The opening: Alegality and political agonism. In Law and agonistic politics, ed. A. Schaap, 57-70. Abingdon/New York: Ashgate.

Lindahl, Hans. 2013. Fault lines of globalization: Legal order and the politics of a-legality. Oxford: Oxford University Press.

Lindroos-Hovinheimo, Susanna. 2012. Justice and the Ethics of Legal Interpretation. New York: Routledge.

MacCormick, Neil. 1978. Legal reasoning and legal theory. Oxford: Oxford University Press.

Mak, Chantal. 2008. Fundamental rights in European contract law. Alphen aan den Rijn: Kluwer.

Mańko, Rafał. 2018. W stronę krytycznej filozofii orzekania. Polityczność, etyka, legitymizacja. Łódź: Wydawnictwo Uniwersytetu Łódzkiego.

Mańko, Rafał. 2020a. The political as an analytical category in the critical study of case law (theoretical model and case study). Krytyka Prawa/Critique of Law 12 (3): 90-108.

Mańko, Rafał. 2020b. Legal form, ideology and the political. In Legal scholarship and the political: In search for a new paradigm, ed. A. Sulikowski, et al., 17-40. Warsaw: C.H. Beck.

Mańko, Rafał, and Jakub Łakomy. 2018. In search for the ontological presuppositions of critical jurisprudence. Krytyka Prawa/Critique of Law 10 (2): 469-486.

McNay, Lois. 2014. The misguided search for the political. Cambridge: Polity Press.

Menga, Ferdinando G. 2017. Conflicts on the threshold of democratic orders: A critical encounter with Mouffe's theory of agonistic politics. Jurisprudence 8 (3): 532-556.

Menga, Feridando. 2018. Antagonism, natality, a-legality. A phenomenological itinerary on the democratic transgression of politico-legal orders. Ratio Juris. An International Journal of Jurisprudence and Philosophy of Law 31 (1): 100-118.

Mercescu, Alexandra. 2018. Pour une comparaison des droits indisciplinée. Basel: Helbing Lichtenhahn Verlag.

Micklitz, Hans-W. 2020. The transformative politics of European private law. In The law of political economy: Transformation in the function of Law, ed. Poul F. Kjaer, 205-227. Cambridge: Cambridge University Press.

Mouffe, Chantal. 1993. The return of the political. London: Verso.

Mouffe, Chantal. 1995. Politics, democratic action, and solidarity. Inquiry 38 (1-2): 99-108.

Mouffe, Chantal. 1999. Deliberative democracy or agonistic pluralism? Social Research 66 (3): 745-758.

Mouffe, Chantal. 2000. The democratic paradox. London: Verso.

Mouffe, Chantal. 2005. On the political. London and New York: Routledge.

Mouffe, Chantal. 2013. Agonistics: Thinking the world politically. London: Verso.

Mouffe, Chantal. 2018. For a Left populism. London: Verso.

Pashukanis, Evgeny B. 1997. Selected writings on law and Marxism. London: Academic Press.

Paździora, Michał. 2019. Constitutionalism in a post-conventional society. Krytyka Prawa/Critique of Law 11 (1): 121-133.

Pichlak, Maciej. 2020. Law in the snares of the political: Addressing Rafał Mańko's Critical Philosophy of Adjudication. Krytyka Prawa/Critique of Law 12 (3): 109-125.

Rodin, Siniša, and Tamara Perišin. 2018. Transformation or reconstitution of Europe: The European critical legal studies perspective. In The transformation or reconstitution of Europe: The critical legal studies perspective on the role of the courts in the European Union, ed. S. Rodin and T. Perišin. Portland: Hart Publishing.

Roskamm, Nikolai. 2015. On the other side 'agonism': 'The enemy', the 'outside', and the role of antagonism. Planning Theory 14 (4): 384-403. 
Schaap, Andrew. 2007. Political theory and the agony of politics. Political Studies Review 5 (1): 56-74. https ://doi.org/10.1111/j.1478-9299.2007.00123.x

Schlag, Pierre. 1990. Normative and nowhere to go. Stanford Law Review 43 (1): 167-192.

Schlag, Pierre. 1991. Normativity and the politics of form. University of Pennsylvania Law Review 139 (4): 801-932.

Schlag, Pierre. 2009. Spam jurisprudence, air law, and the rank anxiety of nothing happening (A report on the state of the art). Georgetown Law Journal 97: 803-835.

Schmitt, Carl. 2005. Political theology: Four chapters on the concept of sovereignty. Chicago: The University of Chicago Press.

Schmitt, Carl. 2007. The concept of the political, trans. G. Schwab. Chicago: University of Chicago Press.

Smoleński, Jan. 2012. Chantal Mouffe vs. Carl Schmitt: The political, democracy, and the question of sovereignty. Hybris 16: 63-81.

Stone, Matthew, Illan rua Wall, and Costas Douzinas. 2014. Law, politics and the political. In New critical legal thinking: Law and the political, ed. M. Stone et al., 1-7, Abingdon: Routledge/Birkbeck Law Press.

Sulikowski, Adam. 2016. Konstytucja—system-hegemonia. "(Anty)polityczna” funkcja argumentów systemowych w orzecznictwie konstytucyjnym. Przeglad Prawa i Administracji 104: 251-263.

Sulikowski, Adam. 2018. Apolityczność w prawoznawstwie: kryzys idei a zjawisko populizmu. Archiwum Filozofii Prawa i Filozofii Spotecznej 3: 74-85.

Sulikowski, Adam, and Mateusz Wojtanowski. 2019. The Polish constitutional court crisis-Some remarks on the political, liberalism and culture. In The gradual emergence of the juristocratic state, ed. B. Pokol and A. Téglási, 181-199. Budapest: Dialóg Campus.

Tacik, Przemysław. 2020. Melancholy of the law. Law and Critique. https://doi.org/10.1007/ s10978-020-09276-6.

West, Robin. 2011. Normative jurisprudence: An introduction. Cambridge: Cambridge University Press.

Yamamoto, Arata D. 2017. Why agonistic planning? Questioning Chantal Mouffe's thesis of the ontological primacy of the political. Planning Theory 16 (4): 384-403.

Žižek, Slavoj. 2008[1989]. The sublime object of ideology. London: Verso.

Žižek, Slavoj. 2017. Incontinence of the void. Cambridge MA: MIT Press.

Publisher's Note Springer Nature remains neutral with regard to jurisdictional claims in published maps and institutional affiliations.

\section{Authors and Affiliations}

\section{Rafał Mańko ${ }^{1,2}$}

\section{Rafał Mańko}

r.t.manko@uva.nl

1 Amsterdam Centre for Transformative Private Law, University of Amsterdam, Amsterdam, The Netherlands

2 Nomos: Centre for International Research on Law, Culture and Power, Jagiellonian University, Kraków, Poland 